\title{
Love beyond continents
}

\section{Entretien avec Jennifer Cole ${ }^{1}$}

\author{
Par Isabelle Jabiot, Maïté Maskens et Carine \\ Plancke
}

\section{Amour et itinéraire de recherche}

Quel est, dans les grandes lignes, votre itinéraire de recherche? Comment en êtes-vous venue à travailler sur l'amour? Comment décriveriez-vous le fait que l'amour se soit immiscé dans votre itinéraire de recherche? Est-ce le résultat d'une évidence ethnographique? Y a-til un lien avec votre expérience et/ou votre environnement personnel/culturel/social?

Vous avez d'abord travaillé sur l'art de la mémoire en lien avec le passé colonial de Madagascar puis sur l'expérience du changement sociale des jeunes citadins à Madagascar. Comment expliquez-vous le fait qu'une enquête et une réflexion sur l'amour soient venues après?

I came to work on love quite by accident, but with hindsight the choice seems inevitable. When I first went to Madagascar, I was influenced by studies of the colonial encounter such as Anne Stoler's work on gender, intimate relations and empire, or John and Jean Comaroff's work on the role of Christianity in the colonization of South Africa. Those books were primarily historical, however, and I was more interested in questions of how the colonial past continued - or not - to shape every day life. I decided to focus my dissertation on social memory and the everyday practices through which people remember and forget the colonial past. To examine these issues, I went to live in a rural village in an area where the French colonial presence had been particularly intrusive, including forced labor, the regroupment of villages, and a bloody anti-colonial uprising. In part because I was interested in the colonial past, and because in rural Madagascar older men are usually considered the keepers of local memory, I spent a lot of time during that first fieldwork period with older men. It was a small community, however, and so it was easy to talk to everyone and I learned about many aspects of social life, including how people in the region thought

1 Professeur en Anthropologie, The University of Chicago. 
about and experienced love. But love was not one of my theoretical preoccupations. I did however become interested in the way affect and emotion shaped patterns of social remembering and both my book and several articles deal with the relationship between memory and emotion (Cole 2001; 2004 ; 2006); so while love was not a theoretical focus in that early research, emotions and affect certainly were. My interest in affect and emotion continued in a later project on youth and temporality that I did with Deborah Durham, where we discussed hope as a kind of sentiment related to the future.

I'd say that the two aspects - an interest in affect and emotion on the one hand and love in particular on the other - really came together when I was working on my second monograph, Sex and Salvation: Imaginging the Future in Madagascar, which focused on urban Malagasy youth and their role in generational change. At the time, Madagascar's economy was rapidly liberalizing and young people had increasingly turned away from schooling as a path to success. Instead, many young women pursued their futures in what I called the sexual economy - a field of social practice where material resources, emotional attachments and social power intertwined and young women engaged in transactional sex as way to obtain consumer goods, and perhaps, a European husband. I followed young people in their everyday lives, and it was really in thinking about their preoccupations with sex and money that I began to see the ways they were also entangled with notions of love. Of course once I began to think about love in their lives, and to ponder how notions of love are bound up with materiality, I also began to think about those issues more generally, including in terms of my own life. I'd still say, however, that it was not concerns with love in my life that led me to take an interest in the topic of love but rather my informants' concerns which prompted me to pursue the topic, which in turn affected how I thought about my own experience.

\section{Appréhender l'amour et conditions de recherches}

Dans l'introduction de votre ouvrage "Love in Africa ", vous investiguez les résistances des chercheurs en sciences sociales à étudier l'amour dans le contexte spécifique du continent africain et ce, pendant de nombreuses décennies. Vous avancez que ces résistances sont liées en partie à la réduction de l'intimité africaine à la seule sexualité et à la perception occidentale d'hypersexualité des Africains, conception qui remplit une fonction de déshumanisation présidant d'idéologies racistes. Est-ce que vous pensez que ces résistances sont définitivement dépassées aujourd'hui ?

Alas, no. I sometimes wonder if they ever will be. It's remarkable how enduring some stereotypes of Africa are, especially in the broader public domain. In the United States, for example, it is not uncommon to find articles in the New York Times, for example, that suggest that African do not feel pain in the same way as Europeans, or that continue to represent Africa in terms of what the journalist Robert Kaplan once

called «The Coming Anarchy.» That said, I do think that generally, at least among 
students and educators, the last several years have seen an increasing senstivity and awareness with respect to the political effects of representations of Africa. In both South Africa and in the American academy over the past year there have been huge debates over the who gets to speak about Africa or African Americans and what they can say. I think what's interesting is that when we wrote Love in Africa, we came to this particular argument about love less through apirori political commitments then by observing contradictions between the people's lived realities on the African continent and the way scholars represented them. In many ways, the argument in Love in Africa is against African exceptionalism, but ideas of African exceptionalism and of Africans' hyper sexuality remain firmly entrenched elsewhere.

Comment la publication de votre ouvrage a-t-elle été reçue ? Est-ce qu'à l'époque, vous avez ressenti que ce thème d'étude souffrait d'un déficit de légitimité ? Si oui, est-ce que vous pouvez nous faire part d'une anecdote ou d'une situation particulière que vous avez vécue qui illustrent ce constat? Estimez-vous qu'aujourd'hui encore l'amour, comme tout ce qui relève du registre émotionnel, reste considéré comme quelque chose de subjectif, d'irrationnel, de féminin etc. ?

My sense is that the book was taken as a welcome antidote to the focus on structural analyses of kinship on the one hand, and a focus on sex and AIDS on the other, which have dominated scholarly depictions of African family life. The reaction of some African women academics was especially telling; I remember bringing a copy of the book to a Malagasy colleague in Paris and how moved she was when she saw the title; my co-editor, Lynn Thomas, had a similar experience with a fellow historian in Kenya. The book clearly hit a nerve; once we pointed to the glaring lack of attention to love in Africa, scholars working in the field of African Studies, whether anthropologists or historians, immediately saw the need for such a book; they also appreciated the intellectual genealogy provided in the introduction. The book appeared around the same time that there was a growing interest in affect in anthropology, as well as several other studies that took up the issue of transnational intimate relations, and so in that sense, it was part of a much wider current of thought.

In many ways, Love in Africa extended the basic feminist insight that the personal is political to the sentimental domain, thereby adding to a growing body of work including Luise White's (1990) The Comforts of Home or Lynn Thomas' (2003) The Politics of the Womb among many others. But there is still a tendancy for studies related to gender in Africa to be cordonned off. While the legitimacy of the topic wasn't an issue per se, there is a general sense that subjects like love as somehow less serious than say, war or politics; as a subject, love is implicitly feminized, and as we know from many other domains, feminization means occupying the marked, particular category in relationship to the unmarked male universal. Long ago in her article on " The Gender of Theory », Catherine Lutz (1995) asked the question, " Is male to female as theory is to ethnography. » Lutz showed that there is a persistent tendency to represent writing by and about women, and issues perceived as feminine, as less important by des- 
ignating them as "ethnograpahy " and not theory. So too, some of the best known theorists of Africa write about phalluses, but they don't write about gender or love. Generally, the book has had the most impact on scholars working on gender, affect and emotion whether in anthropology or history as well as in public health.

\section{Historicités, résistances et légitimité}

Vous avez édité un ouvrage avec l'historienne Lynn M. Thomas intitulé «Love in Africa », quel est selon vous la force du dialogue entre anthropologie et histoire pour étudier les formes de l'expérience amoureuse en Afrique?

Anthropologists study difference and similarity across space, and historians take up these issues across time. By reading these lines of analysis in tandem, one gets a fuller perspective on social life. This observation probably applies to most subjects. It is particularly important for a topic like love which by virtue of its apparent universality who hasn't been in love? who doesn't think (perhaps secretly) that their experience is somehow truer? - tends to lull people into thinking they understand other people's experience. By bringing anthropological and historical perspectives together one can better appreciate the different ways that people have thought about and practiced love. For me, this means paying close attention to how people have conceptialized love - the precise words they have used, the way it has been tied in or not to particular ways of organizing families, gender relations and even political relationships.

Dans votre ouvrage, vous montrez combien les différentes idéologies de l'amour sont marquées par des significations politiques et culturelles particulières. Pour de nombreux jeunes africains d'aujourd'hui, l'attachement au mariage d'amour est une manière de revendiquer une identité "moderne ", se démarquant ainsi des générations précédentes. Cela contribue à générer des tensions générationnelles. Est-ce que vous pensez que ce phénomène est propre au contexte et à l'histoire de l'Afrique?

Hardly. I think that in broad strokes, the association of particular modes of love with modernity or tradition is very relevant to many other parts of the world, including South Asia and the Middle East. Claims to what Jennifer Hirsch and Holly Wardlow (2005) dubbed «modern love» have also become an important part of how people seek to establish themseves as modern subjects more generally. For example, Leiba Fair (2007) has shown how Filipina women in Japan who enter Japan as entertainers and later marry loudly profess their «love» for their husbands as part of a way to claim a modern conception of self associated with a sense of individual interiority. But these widespread patterns are also cross-cut by important differences among regions. The institution of marriage is much stronger in South Asia and the Middle East than in Southern and Eastern Africa, especially, and so people have worked out ways of combining aspects of what they see as modern and traditional modes of arranging marriages - as when the couple meets online and only then do the prospective in- 
laws meet one another and make arrangements, or when the parents arrange a match but the couple still get to meet beforehand. In many contexts where arranged marriages are common one often also finds a conception of marriage where love is said to emerge over the duration of a marriage, rather than being the basis for the marriage in the first place. Although this kind of love is different than the coup-defoudre idea we associate with romantic love, it is useful to remember that until the18th century, passionate love was seen to take place exclusively outside of marriage. It is important, too, to put these different experiences and ways of practicing intense attachments, and how they relate to ideas about modernity, in conversation with one another.

Dans votre introduction, vous posez également la question de l'appropriation de l'idéal romantique comme fondement du mariage africain actuel en termes de pouvoir et de rapport de genre. De nombreuses critiques féministes font apparaitre l'amour romantique comme une "fausse conscience" appuyant les logiques de domination masculine, vous montrez ethnographiquement que dans certains cas, cette appropriation recèle un potentiel libérateur. Comment comprendre ces orientations qui peuvent paraître contradictoires? Ces féministes se trompent?

To say that feminists of the 1970s posed romantic love as harmful to women's interests, and that we argued romantic love is liberatory, is perhaps too sharp a contrast. It helps to put both of our arguments in their social and historical context. Feminists who critiqued romantic love in the 1970s were working from within a Marxist framework that presumed that ideologies like love that work to reinforce the status quo are a form of false consciousness. They weren't particularly interested in questions of cultural variation, a blindspot of Marxism that has long been a point of tension in colonial struggles around the world. We worked on these issues many years later, when the Marxist project had been called into question. Moreover our scholarly sensibilities had been strongly marked by post-colonial perspectives which point out that "woman" is not a universal category. In that spirit, we argued for taking women's perspectives - and their desire to be able to enter into love marriages - seriously. But the normative judgments that flow from that premise are quite another matter. Several chapters in the volume show a real tension between the evident desire on the part of some women to enter into love marriages, and the way such marriages do sometimes operate against women's interests, at least as those interests are perceived by the external observer. One of the reviews of the book even noted that readers with a feminist perspective might find the analyses presented in the book quite bleak. I think that what Love in Africa really shows is that the structures and practices associated with romantic love are neither intrinsically oppressive nor are they necessarily liberatory, and that in any case, as Lila Abu-Lughod observed long ago when she wrote about the romance of resistance, we're always trading in one form of domination or subjugation for another. Romantic love contains certain affordances - it tends to cut people out of families, and to place emphasis on the sentimental satisfaction of 
the conjugal bond. But whether those affordances work to women's advantage or to their detriment really depends on the specific context. Love is both liberating and shackling.

Dans vos travaux actuels, vous décrivez les circuits affectifs qui relient les femmes malgaches - mariés à des hommes français -à leur lieu d'origine. Selon vous, qu'est-ce que les inégalités socioéconomiques font à l'expérience de l'amour?

That is a tremendously difficult question to answer. I think that we fall in love for all sorts of reasons that have nothing to do with equality - and that insofar as we find in others aspects of ourselves that we perhaps wish we had but don't, romantic love is often unequal, although it may be so in ways that are quite different from the kind of sedimented political and economic inequality that clearly characterizes these binational marriages. I do think, however, that gross political and economic inequality affects love by making the question of material resources more salient than they would otherwise be; it limits some of the freedom to choose that are essential to how we think about romantic love in the West. In a sense, gross material inequality contributes to the contrast between "pure" and "self interested" love that have become such an important part of the modern understanding of love, which seems logical, since the opposition between self interest and altruism, gift and commodity, emerged as an outcome of the growth of capitalism. Does that mean that love doesn't exist in these couples? No. But it does mean that people have to work extra hard to overcome the divisions and differences created by political and economic inequality.

Estimez-vous que des barrières culturelles ont été dépassées et qu'il est désormais possible d'appréhender la diversité des manières de concevoir l'amour ? Dans quelle mesure les travaux sur le thème de l'amour sur d'autres continents ont permis de dépasser, voire de remettre en cause, une définition occidentale de l'amour ? À l'inverse, ces travaux ont-il permis selon vous de mettre au jour une dimension universelle de l'amour?

I think that the answer to this question depends in large measure on who one is talking about. Among European and American academics, for example, one can see two trends. On the one hand, anthropologists and historians show a growing appreciation of the diversity of forms of love and seek to decenter Western models. Certainly, scholars working on intimacy largely accept the idea that material resources and sentiments are entangled, rather than opposed. So too most take for granted the idea that while passionate love may be found everywhere, whether it is taken as a sound basis for marriage and the formation of families differs across cultural and historical contexts. At the same time, that some have sought to decenter notions of love however, others have sought to recuperate love as a political idea. For example, Michael Hardt (2011) suggests that we need a properly political conception of love, and that love might provide an alternative to money for organizing social relations. Ironically, the conception of love that he puts forward, however, is one that unselfconsciously repli- 
cates the Euro-American ideology of romantic love. Moreover, it's not clear how far critical approaches to love have seeped into the wider public domain. For example, many people living in various parts of the world including Africa, Asia and the Middle East embrace notions of "modern love" - that is the may aspire to the very models of love that some Western academics seek to decenter. And if the practices of contemporary European states are anything to go by, and as your work on how Belgian bureaucrats decide to whom they will grant a marriage license has aptly shown, the Judeo-Christian notion of romantic love continues to play an important role in the constitution of hierarchical differences and the regulation of migratory flows in Europe. Romantic love separate from material interests, or "clean love" as Malagasy would call it, has become a way to distinguish between good and bad marriage migrants and, as such, an important aspect of contemporary governmentality.

\section{Amour et rapport au terrain et à la discipline}

Face au fait de devoir légitimer son objet de recherche et parce que le chercheur est souvent lié d'une manière particulière à son objet, pourriez-vous nous décrire dans le type d'attachement affectif qui vous lie à vos recherches, le qualifier et nous expliquer la manière dont il a pris naissance et s'est développé ? En quoi cet attachement affectif à ce sujet d'étude est-il ou non distinct des autres sujets d'étude sur lesquels vous avez pu travailler? Le placeriez-vous par exemple au même niveau que la question de la mémoire ou de l'étude du passé colonial, thème plus anciens de vos recherches?

I think that all of my research to date - whether on memory, youth, the sexual economy or evangelical Christianity, has been infused my attachment to Madagascar both to the particlar people I've known there, but also to ways of thinking about the world that long term fieldwork in Madagascar has taught me. Having spent time there on and off for more than twenty years, I've grown up through an engagement with the place. I don't think that my affective attachment to the topic of love is particularly different than the other topics that I've worked on; I do think, however, that the longer I work with Malagasy women around topics of love, money and sexuality, the more I tend to think my own personal experiences through theirs. If you work in a place for a long time, the borders between field and home tend to break down.

Sans tomber dans une image caricaturale du chercheur toujours "passionné" par sa recherche, est-ce que vous pensez que l'amour de la recherche, du terrain et des gens qu'on y rencontre est un élément important de la vie professionnelle de l'anthropologue? Un certain degré d'implication "amoureuse " dans son terrain, est-il une condition pour nouer des liens, pour construire des connaissances et produire une bonne ethnographie (mutualité, d'empathie etc.)?

I think that really depends on the kind of anthropology one is engaged in; there is no one right anthropology and it really depends on the questions posed. Given my inter- 
est in the way personal change is shaped by, and in turn shapes, broader social and ecnomic factors, I think a sense of attachment (love) has probably helped, both in terms of fieldwork and in terms of how I present and analyze the material. But I wouldn't assume that love is a prerequisite for good fieldwork; after all, in some cases love makes us blind, and one of the basic premises of anthropological fieldwork since Malinowski is that it is the particular combination of distance and closeness, estrangement and empathy, that contributes to good ethnography.

Pourquoi choisir de parler d'amour au monde à travers la recherche? Comment expliqueriez-vous votre motivation à faire de la recherche et à travailler sur l'amour? Y a t-il une forme d'engagement dans le choix de "dire » le monde par le biais de l'amour?

I came to work on love quite by accident, while researching youth and the more general question of how people in Madagascar adjusted to and created new futures in the context of economic liberalization. In many ways, that historical moment, in which urbanites seemed sharply torn between economic scarcity on the one hand, and the wealth of commodities that were newly available on the other, made the question of love and its relationship to material resources starkly apparent. But love emerged as a broader theoretical issue because of the gap between my informants' concerns and those of anthropologists. In that sense, I think that the way love emerged as an analytic problem shares much in common with other domains of anthropological research. Moreover, love's ability to foreground the interplay between personal, subjective experience and wider social and cultural contexts is also true of the study of emotions more broadly. In that regard, I think studying love is part of my broader effort to take seriously the role of individual experience in processes of social change, without reproducing American ideologies of heroic individualism. Love - and the question of affect and emotion more generally - offer a terrain on which can glimpse the ways that individual, social and broader political concerns intersect.

\section{Effets sur l'amour d'une recherche sur l'amour}

Apprendre ou chercher "sur » l'amour impacte-t-il, et comment, sur la manière de "vivre », de "faire ", de "performer " l'amour dans sa propre vie quotidienne? Est-ce que le fait de travailler sur cette thématique a eu des répercussions sur votre vie personnelle, sur votre manière d'être "amoureux »? Comment le fait de travailler sur ces thématiques a changé votre regard sur l'amour? Ce travail a-t-il fait évoluer votre définition de l'amour? Quel a été l'impact sur votre rapport à la sociologie et au fait de faire de la recherche? Et sur votre manière d'être avec autrui ?

I think that working on the topic of love has forced me to jettison many of my convictions about what love is or is supposed to look like on the one hand, and has forced me to see similarities between our notions of love and those one finds in Madagascar or across Africa. Whether that has then changed my way of performing love is diffi- 
cult to say, but certainly I'm now hyper aware of the ways in which love and materiality are deeply entangled in one another, in ways that I might have intuited but not made explicit before having done this research. In short, my experience of researching love has done what fieldwork ideally should do: that is help one to both see oneself in the other and see the other in oneself. I don't think it's really changed my manner of engaging in anthropological research because that's probably why I was drawn to anthropology in the first place.

\section{Bibliographie}

COLE J. (2001), Forget Colonialism: Sacrifice and the Art of Memory in Madagascar, Berkeley, University of California Press.

Cole J. (2004), «Painful Memories: Ritual and the Transformation of Community Trauma », Culture, Medicine and Psychiatry, vol. 23, n 1, p. 87-105.

ColE J. (2006), « Malagasy and Western Conceptions of Memory: Implications for PostColonial Politics and the Study of Memory ", Ethos, vol. 34, n² 2, p. 211-243.

Cole J. (2010), Sex and Salvation: Imagining the Future in Madagascar, Berkeley, University of California Press.

Cole J., Thomas L. (dir.) (2009), Love in Africa, Chicago, University of Chicago Press.

FAIER L. (2007), "Filipina Migrants in Rural Japan and Their Professions of Love», American Ethnologist, vol. 34, $n^{\circ} 11$, p. 148-162.

HARDT M. (2011), « For Love or Money », Cultural Anthropology, vol. 2, n 4, p. 676-682.

HiRSCh J., WARdLOW H. (dir.) (2006), Modern Loves: The Anthropology of Romantic Courtship e Companionate Marriage, Ann Arbor, University of Michigan Press.

LuTz C. (1995), « The Gender of Theory », in BEHAR, R., GORDON, D. (dir.), Women Writing, Berkeley, University of California Press, p. 229-266.

MASKENS M. (à paraître), « Screening for Integration and Romance in Brussels' Immigration Office ».

Thomas L. (2003), The Politics of the Womb: Women, Reproduction and the State in Kenya, Berkeley, University of California Press.

White L. (1990), The Comforts of Home: Prostitution in Colonial Nairobi, Chicago, University

of

Chicago

Press. 